\title{
Parathyroid hormone related protein in hypercalcaemia of Hodgkin's disease
}

\author{
J Bolo-Deoku, S Basu, S Lakhani, F Dunne, W A Ratcliffe, M Clarke, J L Barron
}

\begin{abstract}
The role of parathyroid hormone related protein (PTHRP) as a humoral mediator of hypercalcaemia was investigated in a patient with lymphocyte depleted Hodgkin's disease during an episode of hypercalcaemia, using an immunohistochemical staining technique for PTHRP on the tumour tissue and an immunoradiometric (IRMA) assay for PTHRP186 on the patient's plasma. The plasma PTHRP was less than $0.23 \mathrm{pmol} / \mathrm{h}$ in the range found in normocalcaemic controls, and the immunohistochemical staining was not positive for protein. PTHRP did not have a role in the pathogenesis of hypercalcaemia in this patient.
\end{abstract}

\section{Case report}

A 74 year old man presented with widespread lymphadenopathy. There was no history of night sweats, fever, or pruritus. He was occasionally constipated. On examination he had widespread lymphadenopathy and massive hepatosplenomegaly. A chest examination showed reduced air entry, dullness to percussion in the left lung base, and the chest $x$ ray picture showed a mass of soft tissue around the aorta at the level of T12, with pleural thickening at the left lung base. A computed tomography scan showed the presence of a large mass in the left flank which extended inside the chest wall, and there were large nodes around the aorta and in the para-aortic region. Histological examination of the lymph node biopsy specimen showed a diffuse effacement of the nodal architecture by a mixed population of cells, including lymphocytes, plasma cells, mononuclear Hodgkin's cells, classic ReedSternberg cells and pleomorphic Reed-Sternberg cells. The features were of Hodgkin's disease, of the lymphocyte depleted type (figure). His full blood count, liver function, including calcium, albumin, alkaline phosphatase, electrolytes and urea were normal.

Two months later he developed hypercalcaemia and was admitted for treatment and investigations. These included serum calcium $3.12 \mathrm{mmol} / 1 \quad(2 \cdot 20-2.60 \mathrm{mmol} / \mathrm{l})$, inorganic phosphate $1.37 \mathrm{mmol} / 1 \quad(0.84-1.40 \mathrm{mmol} / \mathrm{l})$, albumin $39 \mathrm{~g} / \mathrm{dl} \quad(30-50 \mathrm{~g} / \mathrm{dl})$, creatinine $118 \mu \mathrm{mol} / 1$ (20-110 $\mu \mathrm{mol} / 1)$, urea $11.3 \mathrm{mmol} / 1$ $(2 \cdot 5-7.0 \mathrm{mmol} / \mathrm{l})$, urinary hydroxyproline: creatinine ratio $25 \mu \mathrm{mol} / 1(11-29 \mu \mathrm{mol} / 1)$, urinary phosphate $36.5 \mathrm{mmol} / 24$ hours $(16-48 \mathrm{mmol} /$ 24 hours), urinary creatinine $7.9 \mathrm{mmol} / 1$ $(7 \cdot 0-18.0 \mathrm{mmol} / \mathrm{l})$, renal threshold of phosphate concentration $0.83 \mathrm{mmol} / 1 \quad(0.80$ $1.35 \mathrm{mmol} / \mathrm{l})$, creatinine clearance $41 \mathrm{ml} / \mathrm{min}$ - ute (88-137 $\mathrm{ml} /$ minute), angiotensin convert ing enzyme 57 IU/1 (20-90 IU-1), intac parathyroid hormone (1-84) $1.0 \mathrm{pmol} /$ (1.0-5.7 pmol/1). Protein electrophoresis, thy. roid and liver function tests, including alkaline phosphatase yielded normal results. A bone marrow aspirate showed no evidence of Hodgkin's disease. A skeletal survey showed only severe osteoarthritis with no destructive lesions. PTHRP 1-86 was assayed using a sensitive two site immunoradiometric assay and was found to be less than $0.23 \mathrm{pmol} / \mathrm{l}$ (normocalcaemic controls less than 0.23 ). Immunohistochemical staining, using an antiserum to PTHRP 36-37, was performed on the tumour tissue, which also failed to express the protein. He was rehydrated with physiological saline, pamidronate sodium infusion was given and oral prednisolone $30 \mathrm{mg}$ daily. He became normocalcaemic after treatment and was given chemotherapy consisting of chlorambucil, vinblastine, procarbazine and prednisolone. At the time of writing he was improving clinically and had remained normocalcaemic for over a month.

\section{Discussion}

Hypercalcaemia in malignancy is said to be the result of factors known to cause bone resorption, or from metastases to the bone. The kidney then becomes unable to excrete the excess calcium load which results in hypercalcaemia. Humorally mediated hypercalcaemia of malignancy has been a topic of interest, as a host of bone resorptive factors have been demonstrated, such as prostaglandin $\mathrm{E}$, tumour necrosis factors, interleukin 1 ,

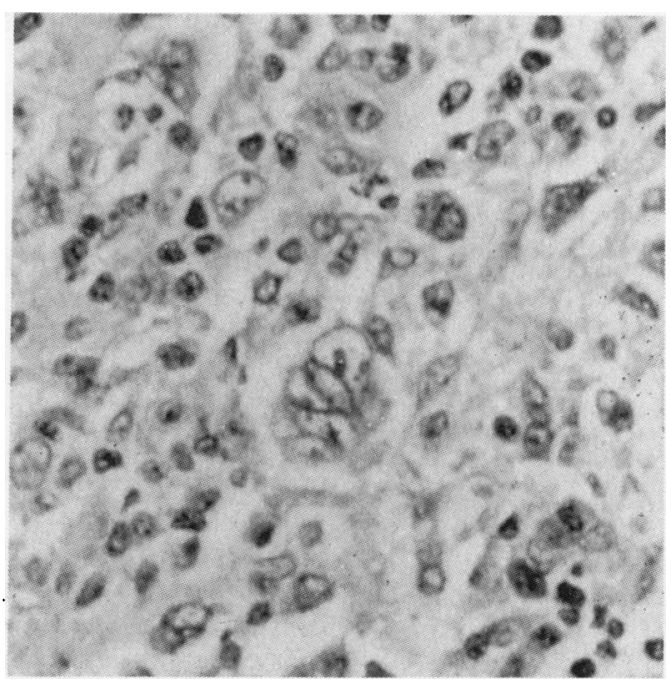

Pleomorphic Reed-Sternberg cell in a background of sparsely cellular infiltrate of lymphocytes, histiocytes and plasma cells (haematoxylin and eosin). 
1,25-dihydroxycholecalciferol and parathyroid hormone like factors. ${ }^{3}$ Hypercalcaemia in haematological malignancies is a well described complication, and humoral factors involved in the pathogenesis are still being investigated, but this presentation is uncommon in this rare subspecialty of Hodgkin's disease. Reports have described hypercalcaemia with no evidence of skeletal metastases or bone marrow abnormalities in Hodgkin's disease, ${ }^{45}$ and established evidence has shown that 1,25-dihydroxycholecalciferol is the factor produced by the tumour. ${ }^{6-8}$ However, Jacobsen et al suggest that 1,25-dihydroxycholecalciferol cannot be the sole humoral mediator of hypercalcaemia in Hodgkin's disease as shown by in vitro bone resorption studies. ${ }^{9}$ Bone resorption activity in a tumour conditioned medium greatly exceeded that attributed to the measured 1,25-dihydroxycholecalciferol; the resorption shown by the medium was dependent on enhanced cycloxygenase activity that was probably produced by a co-factor.

The identification of PTHRP has helped to explain some of the features in hypercalcaemia of malignancy, as it has been implicated as a possible contributing factor in this condition. ${ }^{111}$ The development of different region specific radioimmunoassays and immunohistochemical staining methods on the tumour tissue have made this possible. ${ }^{1212}$ Recent immunohistochemical studies in adult $T$ cell leukaemia/lymphoma (ATLL) have shown the presence of PTHRP in the tumour tissue. ${ }^{13}$ Immunohistochemical staining for PTHRP was performed on formalin fixed, paraffin wax embedded sections of the tumour tissue and control tissue sections, as described previ- ously, ${ }^{2}$ but as shown in our patient, we did not detect PTHRP in the serum nor in the tumour tissue. We conclusively state that PTHRP was not one of the humoral factors associated with the episode of hypercalcaemia in this case of Hodgkin's disease.

1 Ratcliffe WA, Norbury S, Heath DA, Ratcliffe JG. Development and validation of an immunoradiometric assay of parathyrin-related protein in unextracted plasma. Clin parathyrin-related prot

2 Bundred NJ, Ratcliffe WA, Walker RA, Coley S, Morrison JM, Ratcliffe JG. Parathyroid hormone related protein and hypercalcaemia in breast cancer. BMY 1991;303:1506-9.

3 Ralston SH. The pathogenesis of humoral hypercalcaemia of malignancy. Lancet 1987;ii:1443-6.

4 Ellis RD, Beck PR, Mondal BK. Hodgkin's disease presenting with hypercalcaemia. $\mathcal{F}$ Clin Pathol 1989;42:1228.

5 Mayne KM, Bunch C. Hodgkin's disease presenting with hypercalcaemia. f Clin Pathol 1989;42:219.

6 Needle MA, Chandra B. Hypercalcaemia, Hodgkin's disease, and calcitriol. Ann Intern Med 1984;100:916.

7 Rieke JW, Donaldson SS, Horning SJ. Hypercalcaemia and vitamin D metabolism in Hodgkin's disease. Cancer vitamin D metabc

8 Mercier RJ, Thompson JM, Harman GS, Messerschmidt GL. Recurrent hypercalcaemia and elevated 1, 25-dihydroxycholecalciferol levels in Hodgkin's disease. $\mathrm{Am} \mathcal{J}$ Med 1988;84:165-8.

9 Jacobson JO, Bringhurst FR, Harris NL, Weitzman SA, Aisenberg AC. Humoral hypercalcaemia in Hodgkin's disease. Cancer 1989;63:917-23.

10 Ralston SH, Danks J, Hayman J, Fraser WD, Stewart CS Martin TJ. Parathyroid hormone related protein of malienancy: Immunohistochemical and biochemical in: Imminemical with cancer. $f$ Clin Pathol 1991;44:472-6.

Heath DA, Senior PV, Varley JM, Beck F. Parathyroid hormone related protein in tumours associated with hypercalcaemia. Lancet 1990;335:66-9.

12 Danks JA, Ebeling PR, Hayman J, et al. Parathyroid hormone related protein of cancer; immunohistochemical localization in cancers and in normal skin. $\mathscr{f}$ Bone Min Res 1989;4:273-7.

13 Moseley JM, Danks JA, Grill V, Lister TA, Horton MA. Immunocytochemical demonstration of PTHrP protein in neoplastic tissue of HTLV-1 positive human adult T cell leukaemia/lymphoma: implications for the mechanism of hypercalcaemia. Br $\mathcal{F}$ Cancer 1991;64:745-8.

\title{
Increase in severity of graft versus host disease by cytomegalovirus
}

\author{
A L McCarthy, J S Malik Peiris, C E Taylor, M A Green, L Sviland, A D J Pearson, \\ A J Malcolm
}

Department of
Pathology, Royal
Victoria Infirmary,
Newcastle upon Tyne
NE1 4LP
A L McCarthy
M A Green
L Sviland
A J Malcolm
Department of
Virology
J S Malik Peiris
C E Taylor
Department of Child
Health
A D J Pearson
Correspondence to:
Dr A L McCarthy
Accepted for publication
30 October 1991

Department of

Victoria Infirmary,

Newcastle upon Tyne

A L McCarthy

A J Malcolm

Department of

Virology

J S Malik Peiri

Department of Child

Health

A D J Pearson

Dr A L McCarthy

30 October 1991

\begin{abstract}
An allogeneic transplant recipient developed severe graft versus host disease (GvHD) 48 days after transplantation that was concomitant with a cytomegalovirus (CMV) viraemia, from which she subsequently died. CMV infection was detected in blood by the polymerase chain reaction and later in tissue by immunohistochemical techniques. CMV should be considered in patients in whom GvHD does not respond to appropriate treatment, and this case suggests that herpes viruses may increase the severity of GvHD by . synergistically enhancing the graft versus host reaction.
\end{abstract}

Graft versus host disease (GvHD) is a major complication of bone marrow transplantation (BMT) and continues to be the main factor that currently limits allogeneic BMT. ${ }^{1}$ An increasing number of studies over the past decade have reported an association between herpes viruses and GvHD and, in particular, the frequent clinical association of cytomegalovirus (CMV) with GvHD. ${ }^{2-5}$ Attempts to link herpes virus infection and GvHD in a causal relationship have so far mainly been based on serological studies. No previous study, as far as we know, has examined the target organs in GvHD for viral infection.

The organs affected in GvHD are primarily the skin, gut, and liver. We have been pro- 